\title{
The Effect of Business Enabling Policies, Tax Treatment, Corruption and Political Connections on Business Climate
}

\section{Gentjan Çera $^{1}$, Pavla Breckova ${ }^{2}$, Edmond Çera ${ }^{1}$, Zoltan Rozsa ${ }^{3}$}

${ }^{1}$ Tomas Bata University in Zlín, Faculty of Management and Economics, Mostní 5139, 76001 Zlín, Czech Republic.E-mail: cera@utb.cz, ecera@utb.cz

${ }^{2}$ University of Finance and Administration, Faculty of Economic Studies, Estonska 500, 10100 Prague, Czech Republic. E-mail: pavla.breckova@vsfs.cz

${ }^{3}$ School of Economics and Management in Public Administration in Bratislava, Furdekova 16, 85104 Bratislava, Slovakia. E-mail: zoltan.rozsa@vsemvs.sk

\begin{abstract}
The impact of the institutional environment on the business activity was a subject of several previous studies. However, the ways in which changes in institutions affect business climate have not received proper attention from scholars as of yet. The purpose of this paper is to fill this gap in the literature by examining the relationship between selected formal institutions (business enabling policies and tax treatment) and informal institutions (corruption and political connections) and business climate in the context of the developing country. To test the proposed hypotheses an ordinal regression with two link functions was applied on an original dataset of 404 firms operating in Albania. Results show that neither formal institutions, nor informal ones act as a block concerning the impact on the business climate. Tax treatment and political connections affected business climate negatively, whereas corruption seemed to have a positive impact. A positive but insignificant effect was found between business enabling policies and the business climate. Our research triggers interest of policymakers who intend to design policies to improve the business environment.
\end{abstract}

Keywords: business climate; business enabling policies; tax treatment; corruption; political connection

\section{Introduction}

Research problem. The state of activity (productive, unproductive or destructive) in the economy is determined by the institutional environment in which the activity is carried out [1]. This implies that the change of the institutional framework affects the entrepreneurial activity by influencing the business environment [2]-[4]. Therefore, as suggested in the literature [5], [6], certain 
interconnection of institutions and the business climate is envisaged. However, ways in which changes in institutional environment affect the business climate have not received sufficient attention from scholars [7], [8]. In order to fill this gap in the literature, our research focuses on examining the relationship between formal and informal institutions and the business climate in the context of the transition economy, specifically Albania.

The contribution of the previous research, where the institutional theory was developed [9]-[11], drives us to create institutional factors affecting the business climate. An institution can be formal or informal, and it has the capability to influence entrepreneur's attitude or behavior by constraining or supporting his activity [9]. Formal institutions are considered crucial for the business activity - if they are stable and operating efficiently, they have a potential to reduce the business risk and uncertainty [12], [13]. Along with others, business enabling policies and tax administration or tax treatment are considered as formal institutions. On the other hand, informal institutions in the economy that are related to the legacy of the past, certain business practices and traditional social behavior may constrain entrepreneurial activity [14]-[16]. Corruption and unfair competition are typical informal institutions. Unfair and/or informal competition is related to political ties because entrepreneurs linked to politicians may benefit from avoiding law requirements [17], [18].

According to both official reports and previous studies, informal competition, corruption and tax administration were among the top business environment obstacles identified by Albanian entrepreneurs [19]-[21]. Entrepreneurial activity, carried out primarily by small and medium-sized enterprises (SMEs), makes an important contribution to the Albanian economic growth [22]. SMEs contribute more than $70 \%$ of value added and account for more than $80 \%$ of employment. Compared to the European Union (EU), SMEs crate an average value added of $57 \%$ and an average employment rate of $70 \%$ [23]. Given these figures, entrepreneurship support should be of a particular interest to Albanian policymakers. In addition, improving the business climate may also lead to attracting foreign direct investments and to developing a better functioning market economy, particularly in the Western Balkans [24], [25].

A reasonable level of governance leads to the strengthening of those formal institutions that enable and support entrepreneurial activity. At the same time, it leads to weakening those informal institutions that constrain it. Based on the eclectic theory of entrepreneurship, Verheul et al. [26] found that government influences the demand and supply sides of business activity. More recently, using the same theory, Thai and Turkina's study [27] concluded that the effect of governance is positive on formal institutions and negative on informal ones. The current paper aims to investigate these effects on business climate in the context of a transition and developing economy. Moreover, business climate is not affected by all formal institutions in the same way, nor by the informal ones. Another strand of literature suggests that the effect of institutions in transition and 
emerging economies is in contrast to what is expected in developed countries. This aspect is more present especially in the case of informal institutions. For instance, corruption has a positive association with business growth [28] or with an innovative activity [29]. On the other hand, economic, institutional and political environments play an important role in the relationship between political connections and business performance [30].

Aim and motivation. This paper seeks to explore the relationship between business climate and selected formal and informal institutions in the context of a transition economy. For analysis purposes, business enabling policies and tax treatment are selected as formal institutions, and corruption and political connections as informal ones. In the course of conducting this study, significant evidence of this relationship being explored has not been found, in particular in the context of a transition economy. The results of this research may be of a particular interest to policymakers that intend to improve the business environment and to foster business start-ups. As Fereidouni and Masron [31] claim, from the point of view of the policymakers, it is very important to know which institutions matter the most for entrepreneurs and what their impact on business climate is.

Next part of this paper is dedicated to the literature review on the formal and informal institutions and developing the research hypotheses. Further part (no. 3) covers the issues related to the measurement of variables, the composite variables reliability test, the statistical method and the data collection technique. Analyzed results are presented in Section 4, and the Section 5 is dedicated to the discussion. At the end of the paper the concluding remarks are presented.

\section{Literature Review}

Structure of a country's institutional environment is made of formal and informal components [9], [11]. The institutions shape business environment and, consequently influence the business climate conditions in the economy.

Formal institutions are rules communicated through official channels, and consist of a regulatory framework and policy tools. They include the complexity and enforcement of the regulations in a country. Heavily regulated framework and unfriendly business policies may impede business start-ups and can discourage individuals from taking actions to become an entrepreneur [2], [32]. Therefore, formal institutions, such as business enabling policies and tax treatment affect business climate by stimulating or deterring entrepreneurial activity.

To encourage market entry and entrepreneurial activity, business enabling policies aimed at business environment improvement should be considered by policymakers [31], [33], [34]. Governmental interventions in the economy can lead to the improvement of business climate. Bjørnskov and Foss [35] argued that 
the impact of entrepreneurship activities on productivity increases as the government becomes more active in the economy. Similar results were explored also by Fereidouni and Masron [31]. Likewise, Surfield and Reddy [36] found that business climate coincides with a lower rate of job loss. According to Blume [37], the local economic policies are associated with the business climate. Consequently, the firms' satisfaction with economic policies is associated with a set of factors related to the business environment. Nevertheless, other scholars argue that in a short-run policymakers cannot do much to change or reshape the industry profile in the country, whereas, in a long-run government involvement in public investments in education or infrastructure can affect the economy by shifting it from one set of industries to another [38]. Government can enable (designing policies) or constrain (through regulations) business start-ups and entrepreneurial activities [39]-[42]. The presence of good program aiming at assisting SMEs provided by government leads to a quality business environment [2]. Conversely, Xheneti and Bartlett [20] by performing principal component analysis and hierarchical linear regression, found that support-related impediments do not influence Albanian company growth. Similarly, Čadil et al. [43] studied the cohesion policy support for SMEs designed by European Commission in the context of the Czech Republic by applying a quasi-experimental research design and concluded by finding no impact of such policy on the value added and value added per labor cost of SMEs. Based on this discussion the following hypothesis can be proposed:

Hypothesis 1 (H1): Business climate is positively affected by business enabling policies.

Tax treatment can influence the business environment the firms operate in. Compared to high-income countries, tax administration is identified as a problem especially in middle-income countries [5], [44]. Similarly, in Central and South East European countries entrepreneurs perceive the level of taxes and, in particular tax administration, as one of the major obstacles for the business growth [28], [45], [46]. Changes in tax legislation and administration are among the most important impediments identified by Albanian entrepreneurs [20], [21]. Concerning the relation between taxation and entrepreneurship, the consensus is absent in empirical research [47]. Stallmann and Deller [48] found evidence that taxes limitations are associated with a poorer business climate and lower economic performance. Furthermore, Braunerhjelm and Eklund [49] examined the tax administration and found a negative relationship between firms' market entry and tax administrative burden. Following the Sobel's work [8], Chowdhury et al. [2] considered tax rates as a key formal institution determining entrepreneurship quality. They established a negative and significant relationship between them. Countries with cumbersome regulations have lower rates of business start-ups [50], [51] and do not stimulate a business growth [15]. For instance, complicated tax regulations might force business owners to hire external advisors to deal with 
tax procedures and administration, which consequently raises their costs. Therefore, we hypothesize:

Hypothesis $2(\mathrm{H} 2)$ : Tax treatment has a negative effect on business climate.

Informal institutions are socially shared rules, usually not written that are communicated through unofficial channels [9]. They are deeply rooted values and norms which can influence individual behavior.

In transition economies, informal institutions are expected to be important drivers for business start-up and an entrepreneurial activity. The reason could be weak formal institutions originating from communist rule, and also inadequate institutional reforms during the transition period [17], [20]. As Belitski et al. [47] argued, a country characterized by an inadequate formal institutional environment may lead to additional pressure on informal institutions to shape organizational behavior.

Corruption is considered a classical informal institution [15] especially in transition economies [17]. It may transfer resources towards more corruptible activities because firms want to benefit from them [52]. Several researchers refer to corruption as an influential factor of business activity [31], [53], however, in the academic sources there is no consensus on the direction of its effect [29], [52], [54]. Grosanu and Bota-Avram [55] rated control of corruption as an important factor for the business environment, particularly for business start-up. Other studies have also found evidence that corruption hurts entrepreneurial activity [56], [57]. Dutta and Sobel [58] concluded that the corruption effects remain negative, but become smaller when business climate is not corruption-favorable. Nevertheless, another strand of the empirical research shows that corruption may help firm's market entry and entrepreneurial activity [16]. In the countries of South-Eastern Europe, corruption had a positive effect on business growth, whereas in the countries of Central-East Europe the opposite effect was observed [28]. Interpretation of such results could be related to deeply rooted social acceptance of corruption [59] in economies characterized by weak formal institutions. Furthermore, business owners from Western Balkan tend to justify corruption as "greasing the wheels" of business [60]. Based on this evidence in the context of a transition economy, the following hypothesis can be formulated:

Hypothesis 3 (H3): Business climate is positively affected by corruption.

Whether corruption is damaging or helping entrepreneurship can depend on the company's political connections. Political connections are other informal institutions that influence business activity. Linkages with politicians (at local or national level) can help business owners to facilitate transactions and gain benefits to improve their business [61]. In countries with weak institutions, especially in post-communist countries, entrepreneurs tend to engage in political activities [17], [18]. Such engagement leads to potential benefits that government officials may offer in the future, leading to informal competition. The informal sector 
competitor's procedures are identified by enterprises as the main obstacle for doing business in some European countries and Central Asia [5]. This is in line with what researchers have documented in the Albanian business environment: business entities consider unfair competition as an obstacle [21]. In addition, due to their greater experience, social and potential political relationships, senior (older) entrepreneurs are more active in connection with government officials [20].

On the other hand, political connections are influenced by the prevailing institutional and political environment at a national level, by the business characteristics [62] and also by the economic environment [30]. Therefore, the political, institutional, and economic environments shape the relationship between political connections and business performance [30]. Companies that have ties with politicians might perform better [63], [64] and they also take a lower risk compared to the businesses with no political connections [52]. Amore and Bennedsen's [65] research results indicated that doing business with the public sector is an important channel for transferring rent to connected firms, which increases their profitability. Contrary to these empirical studies, however, some researchers have found the opposite: business performance is reduced by political connections [30]. Due to political instability and frequent changes in governmental officials, companies may be exposed to a risky and unstable political connections. As a result, the business climate is expected to be affected by political connections. Therefore, we assume the hypothesis:

Hypothesis 4 (H4): Political connections influence the business climate negatively.

\section{Methods and Procedures}

Unit of analysis. The unit of the analysis was a company. A face-to-face structured interview was performed with a member of each management team. As with Jolley, Lancaster and Gao [66], the owner, co-owner, financial manager, director, deputy director or manager was considered to be the appropriate person to represent the company's viewpoints.

Variable measurement. Tax treatment, corruption, political connections and business enabling policies were composed by the mean of a selected item set different per each variable. This type of variables creation has been commonly used in the literature (i.e. Batsakis [46]). The tax treatment represented by the following items: "Tax officials are competent and knowledgeable", "Tax officials are fair in their assessments and decisions", "Government is doing a good job in services offered to my business", and "There are many benefits for businesses that pay taxes". Political connections variable consisted in the item set: "Companies are involved in the local political activities", "Relationships between senior 
government officials and some private sector entities include bribes or other benefits", and "Political favoritism impacts on business activity in the private sector." Corruption variable had a following item set: "In this business branch, it is common for companies to provide informal pays to get things done with regard to customs, taxes, licenses, regulation, etc.", "In this business branch, companies are familiar with the amount of informal payments to get things done", "Bribery and corruption remain an inevitable cost of doing business in my country", and "Bribery and corruption remain an inevitable cost of doing business in the Balkans." Business enabling policies variable was represented by these items: "Public investment in infrastructure has had a direct and positive impact on my firm's operations", "Public investment in the energy supply has had a direct and positive impact on my firm's operations", "Public investment in education has had a direct and positive impact on my firm's operations", and "Public investment in health services has had a direct and positive impact on my firm's operations". The items of tax treatment and corruption were formulated as a five-point Likert scale, $1=$ "fully disagree" to $5=$ "fully agree", whereas those of political connections and business enabling policies were in a form of four-point scale, $1=$ "no, not at all" to 4 = "completely".

Business climate was measured by one question: how do you perceive current business climate / doing business conditions? Respondents were supposed to choose one of the three listed options: 1 = "unfavorable", 2 = "normal" and $3=$ "favorable". This type of measurement makes business climate an ordinal variable, which limits the use of statistical methods.

Reliability test. Before computing the mean of item sets per each variable, the reliability of the scales was checked. Reliability test checks whether the measure reflects the construct that it is measuring or not. Table 1 shows the results of Cronbach's alpha, which is a test of reliability along with the mean and standard deviation per each item and composed variable. Considering DeVellis's [67] criteria, business enabling policies and corruption were respectable (between .70 and .80), whereas tax treatment and political connections were minimally acceptable (between .65 and .70).

Table 1

Cronbach's alpha per each composed variable and expected sign

\begin{tabular}{|ll|ccccc|}
\hline Institution & Composed variables & Number of items & Mean & SD & $\alpha$ & Expected sign \\
\hline \multirow{2}{*}{ Formal } & Business enabling policies & 4 & 1.86 & .69 & .750 & + \\
& Tax treatment & 4 & 3.37 & .96 & .677 & - \\
\hline Informal & Corruption & 4 & 2.84 & 1.13 & .749 & + \\
& Political connections & 3 & 2.55 & .70 & .675 & - \\
\hline
\end{tabular}

Note: SD is standard deviation, $\alpha$ is Cronbach's alpha

The relation between business climate and our variables is shown in the Table 1 . An improvement in business enabling policies and corruption may lead to a better 
business climate, whereas, if tax treatment and political connections increase, business climate tends to become unfavorable for doing business generally.

Methods. To examine the effect of business enabling policies, tax treatment, political connections and corruption on business climate ordinal regression was employed. Ordinal regression is a statistical technique used to predict behavior of ordinal level dependent variables with a set of independent variables. As compared to multinomial logit model, it estimates one equation over all levels of the response variable. Dependent variable is the order response category variable and independent variable may be categorical or continuous. Our dependent variable was business climate, which was an ordinal variable (1 = "unfavorable", 2 = "normal" and 3 = "favorable"). There are five link functions that can be applied in an ordinal regression: logit, probit, $\log$-log (also known as negative log$\log$ ), complementary log-log and cauchit [68, p. 362]. The link function is a transformation of the cumulative probabilities of the ordinal outcome to be used in the estimation of the model. In this paper, the logit and log-log are employed. They predict the probability of a certain level or category of dependent variable $(\gamma)$ occurring with respect to the known values of the independent variables $\left(X_{i}\right)$, and their equations are as follows:

\begin{tabular}{lcc} 
Link name & Function & Inverse \\
\hline Logit & $P(\gamma)=\frac{1}{1+e^{-\left(\beta_{0}+\beta_{1 i} X_{1 i}\right)}}$ & $\ln \left(\frac{\gamma}{1-\gamma}\right)=\beta_{0}+\beta_{1 i} X_{1 i}$ \\
Log-log & $P(\gamma)=e^{-e^{-\left(\beta_{0}+\beta_{1 i} X_{1 i}\right)}}$ & $-\ln (-\ln \gamma)=\beta_{0}+\beta_{1 i} X_{1 i}$
\end{tabular}

According to Norušis [69], logit should be applied if evenly distributed categories of the dependent variables are noticed, whereas log-log is recommended to be applied if lower categories are more likely. The analyses were computed by means of statistical package SPSS version 23. The SPSS Ordinal Regression procedure, known as PLUM (Polytomous Universal Model), was essential to generate the ordinal regression results. PLUM is an extension of the general linear model to ordinal categorical data [69].

Data and sample profile. In the survey, there were 404 businesses involved in Albania. Observations were conducted by IDRA Research and Consulting, a market research company based in the capital city. Data collection and quality control were completed in January 2017. For the distribution of the sample, the General Directorate of Taxation business database was used, and in order to ensure the representativeness of the results, the following criteria have been taken into account: county (12 counties), business size (number of employees) and business sector (manufacturing, service and trade). The questionnaire was a semiadaptation of previous similar surveys by the International Labor Organization. 
Table 2 introduces the final survey dataset and the results of the business climate in Albania. About 58\% of the observed data was collected from the companies located in the capital, $23 \%$ from the south, $11 \%$ from the central and $8 \%$ from the northern part of the country. It corresponds with the real business distribution throughout Albania. In Tirana, the capital, there is a major part of the Albanian business located. The northern region has the lowest number of businesses compared to other regions, although it includes four different counties. That is due to the level of economic development and low population density in these areas. According to sectoral industries in the survey sample, there were about $17 \%$ manufacturing companies, $40 \%$ trade, $45 \%$ services and the rest of the examined sample represented another activity $(6 \%)$.

When analyzing the data, most businesses see the business climate as "unfavorable". The highest score was recorded in the capital (63\% "unfavorable"). Less than one in seven firms rated the business climate as favorable in Albania. Table 2 shows the results disaggregated by region and business activity.

Table 2

Sample profile and the distribution of business climate categories across regions and business activities

\begin{tabular}{|c|c|c|c|c|c|c|}
\hline & \multicolumn{3}{|c|}{ Business climate } & \multicolumn{2}{|c|}{ Total } \\
\hline & & Unfavorable & Normal & Favorable & $n$ & $\%$ \\
\hline \multirow[t]{4}{*}{ Region } & South & $57 \%$ & $29 \%$ & $14 \%$ & 92 & $23 \%$ \\
\hline & North & $50 \%$ & $28 \%$ & $22 \%$ & 32 & $8 \%$ \\
\hline & Central & $50 \%$ & $46 \%$ & $4 \%$ & 46 & $11 \%$ \\
\hline & Capital city & $63 \%$ & $23 \%$ & $14 \%$ & 232 & $58 \%$ \\
\hline \multirow{5}{*}{$\begin{array}{l}\text { Business } \\
\text { activity }\end{array}$} & Manufacturing & $61 \%$ & $34 \%$ & $4 \%$ & 67 & $17 \%$ \\
\hline & Trade & $56 \%$ & $28 \%$ & $16 \%$ & 162 & $40 \%$ \\
\hline & Services & $59 \%$ & $25 \%$ & $16 \%$ & 149 & $37 \%$ \\
\hline & Others & $71 \%$ & $21 \%$ & $8 \%$ & 24 & $6 \%$ \\
\hline & Share & $59 \%$ & $28 \%$ & $14 \%$ & 402 & $100 \%$ \\
\hline
\end{tabular}

\section{Results}

The mean, standard deviation and number of observations by business climate categories for each analyzed variable are quoted in Table 3. The mean of tax treatment had a negative trend across the business climate (from 3.61 for unfavorable level to 2.98 for favorable level), whilst business enabling policies had a moderate positive trend. Based on these trends in the data, it was expected that ordinal regression would bring a positive sign between business climate and business enabling policies, and a negative sign with tax treatment. On the other hand, a negative trend was observed when business climate levels increase in cases of political connections, and the positive trend was marked in case of 
corruption. Consequently, a negative association can be expected between business climate and political connections, and a positive one with corruption.

Table 3

Descriptive statistics of observations by business climate categories for each variable

\begin{tabular}{|l|cccccccccccccc|}
\hline \multirow{3}{*}{ Variable } & \multicolumn{10}{|c|}{ Business climate } \\
\cline { 2 - 12 } & \multicolumn{1}{|c|}{ Unfavorable } & \multicolumn{1}{c|}{ Normal } & \multicolumn{4}{c|}{ Favorable } & \multicolumn{3}{c|}{ Total } \\
& Mean & SD & $n$ & Mean & SD & $n$ & Mean & SD & $n$ & Mean & SD & $n$ \\
\hline Business enabling policies & 1.81 & .66 & 235 & 1.85 & .65 & 111 & 2.12 & .83 & 55 & 1.86 & .69 & 401 \\
Tax treatment & 3.61 & .98 & 236 & 3.04 & .74 & 111 & 2.98 & .96 & 55 & 3.37 & .96 & 402 \\
Corruption & 2.62 & 1.16 & 230 & 3.06 & 1.06 & 110 & 3.32 & .95 & 55 & 2.84 & 1.13 & 395 \\
Political connections & 2.72 & .69 & 218 & 2.33 & .58 & 101 & 2.21 & .69 & 52 & 2.55 & .70 & 371 \\
\hline
\end{tabular}

Note: SD stands for standard deviation and $n$ represents the number of observations

An ordinal regression analysis was performed to assess the prediction of affiliation with one of three outcome levels on the basis of four covariates. Our outcome variable was business climate $(1=$ "unfavorable", $2=$ "normal" and $3=$ "favorable") and the covariates used were tax treatment, political connections, corruption and business enabling policies, all scale measured. After deduction of 38 cases with missing values on our covariates, data of 366 companies remained suitable for analysis. Although the three levels of output were unevenly distributed, the logit link function was performed. A detailed look at frequencies of business climate categories (refer to Table 2) may lead to the selection of the negative log-log link function. Lower categories of business climate were more likely, thus the log-log link function was used.

Table 4

Model fit, goodness-of-fit and test of parallel lines for two types of ordinal regressions

\begin{tabular}{|ll|lcccc|}
\hline Link function & & \multicolumn{2}{|c}{-2 Log likelihood } & Chi-Square & df & Sig. \\
\hline Logit & Model fitting & & 627.903 & 62.837 & 4 & .000 \\
& Test of parallel lines & & 621.678 & 6.225 & 4 & .183 \\
\cline { 2 - 7 } & Goodness-of-fit & Pearson & & 713.948 & 710 & .451 \\
& & Deviance & 626.517 & 710 & .989 \\
\hline \multirow{2}{*}{ Log-log } & Model fitting & & 632.965 & 57.776 & 4 & .000 \\
& Test of parallel lines & & 627.098 & 5.866 & 4 & .209 \\
\cline { 2 - 6 } & Goodness-of-fit & Pearson & & 701.144 & 710 & .586 \\
& & Deviance & 631.578 & 710 & .984 \\
\hline
\end{tabular}

In Table 4, the summary of data for both conducted models is presented. Regarding the ordinal logistic regression (logit), the results indicate the overall model was statistically significant, $\chi^{2}(4, n=366)=62.837, p<.001$. Also, there was a good model fit (discrimination among levels) on the basis of our four covariates, $\chi^{2}(710, n=366)=626.517, p=.989$, using a deviance criterion. In addition, evidence showed no violation of the parallel lines assumptions, that state the slope coefficients in the model were the same across response categories (and 
lines of the same slope were parallel), $\chi^{2}(4, n=366)=6.225, p=.183$ (referring the first block of Table 4). A violation of this test leads to the less restricted model usage, i.e. multinomial logit model [68]. As the ordinal logistic regression, similar results were found even in the case of log-log link function (second block of Table 4 ). The fitting of the model was statistically significant, $\chi^{2}(4, n=366)=57.776, p$ $<.001$, and deviance criterion reported the good model fit based on our four covariates, $\chi^{2}(710, n=366)=631.578, p=.984$. Also, its test of parallel lines was not violated indicating that slope coefficients are the same among the dependent variable categories, $\chi^{2}(4, n=366)=5.866, p=.209$. Therefore, the results provided by both link functions are not misleading.

Table 5 contains a summary of parameter estimates for both link functions. To differentiate the dependent variable levels, the ordinal regression has an algorithm that calculates a continuous latent variable [68]. The thresholds [Business climate $=1]$ and [Business climate $=2$ ] represent the response variable in the ordinal regression. The estimated threshold for [Business climate $=1$ ] is the cutoff value between unfavorable and normal business climate levels and the threshold estimate for [Business climate $=2$ ] represents the cutoff value between normal and favorable business climate levels. Thus, [Business climate $=1$ ] is the estimated cutpoint on the latent variable used to differentiate unfavorable business climate from normal and favorable business climate levels, when all factors and covariates are zero. Subjects that had a value of -1.70 (logit vs $\log -\log :-0.81$ ) or less on the underlying latent variable that caused a rise in our dependent variable would be classified as unfavorable. In this line, [Business climate $=2$ ] is the estimated cutpoint on the latent variable used to differentiate unfavorable and normal categories from favorable category of business climate, if values of all factors and covariates are zero. Subjects (entrepreneurs) with a value of -0.05 (logit vs log-log: 0.52) or greater on the underlying latent variable that rose our dependent variable would be classified as favorable business climate. Subjects with a value between -1.70 and -0.05 (logit vs $\log -\log$ : -0.81 and 0.52 ) on the underlying latent variable would be classified as normal business climate. According to logit link function's output, only the threshold of [Business climate $=1]$ proved to be statistically significant.

There was found a statistically significant effect of the tax treatment, political connections and corruption on business climate in both link functions. Referring to the case when logit was applied as a link function, if an entrepreneur was to increase his perception in tax treatment score by one point, his ordered log-odds of being in a higher business climate category would decrease by 0.47 , while the other variables in the model are held constant. Alternatively, an increase by one unit in tax treatment, the odds of the unfavorable and normal categories of business climate versus to the favorable category of business climate was 0.62 times greater, given that the other variables in the model are held constant, $p<.01$. Because of the proportional odds assumption (referring to the test of parallel lines in Table 4), the same increase, 0.62 times, is found between unfavorable business 
climate and the combined categories of normal and favorable business climate. Like the logit case, the model where log-log was applied as link function reported a statistically significant negative association between business climate and tax treatment. Therefore, the evidence supported our expectation related to the sign of the relationship between tax treatment and business climate leading to the acceptance of $\mathrm{H} 2$. Despite the positive sign, business enabling policies were insignificant in the predicting the company's affiliation with one of the three levels of business climate, which implies the rejection of $\mathrm{H} 1$.

Table 5

Results of two types of ordinal regressions

\begin{tabular}{|l|cccc|crr|}
\hline \multirow{2}{*}{ Variable } & \multicolumn{3}{|c|}{ Logit $^{\mathrm{a}}$} & \multicolumn{3}{c|}{ Log-log $^{\mathrm{b}}$} \\
\cline { 2 - 8 } & Estimate & OR & $\begin{array}{c}95 \% \text { CI } \\
\text { Lower Upper }\end{array}$ & Estimate & $\begin{array}{c}95 \% \text { CI } \\
\text { Lower Upper }\end{array}$ \\
\hline [Business climate $=1]$ & $-1.70(.86)^{*}$ & & & & $-0.81(.64)$ \\
[Business climate $=2]$ & $-0.05(.86)$ & & & & $0.52(.65)$ & \\
Business enabling policies & $0.17(.16)$ & 1.19 & 0.88 & 1.62 & $0.14(.11)$ & -0.08 & 0.37 \\
Tax treatment & $-0.47(.12)^{* * * *}$ & 0.62 & 0.49 & 0.79 & $-0.34(.09)^{* * *}$ & -0.52 & -0.16 \\
Corruption & $0.25(.11)^{* *}$ & 1.28 & 1.03 & 1.58 & $0.15(.08)^{*}$ & -0.02 & 0.31 \\
Political connections & $-0.60(.18)^{* * *}$ & 0.55 & 0.39 & 0.79 & $-0.41(.14)^{* * *}$ & -0.68 & -0.15 \\
\hline
\end{tabular}

Note: $* p<.10, * * p<.05, * * * p<.01$, The numbers in parentheses are standard errors, CI is confidence interval, OR is odds ratio. a. $R^{2}=.158$ (Cox \& Snell), .186 (Nagelkerke), .091 (McFadden). b. $R^{2}=$ .146 (Cox \& Snell), .172 (Nagelkerke), .083 (McFadden).

In contrast to tax treatment effect, corruption displayed a positive effect on business climate. When logit was employed as a link function, an increase by one unit of business' perception in corruption, the odds of favorable business climate versus the combined unfavorable and neutral categories were 1.28 times greater, with a $95 \%$ confidence interval between 1.03 and $1.58, p<.05$. The positive association was reported even when log-log had been applied as a link function, but the significance was a bit weaker compared to the case of logit, $p<.10$. Therefore, we failed to reject the $\mathrm{H} 3$.

Contrary to corruption variable, the increase by one unit in business' perception in political ties, the odds of business climate being favorable compared to unfavorable and normal categories were 0.55 times greater, with a $95 \%$ confidence interval that laid between 0.39 and $0.79, p<.01$. The significance and a negative association between political connections and business climate was found even in case when log-log had been used as link function. Thus, this evidence supports $\mathrm{H} 4$. 


\section{Discussion}

Our findings show that the impact of formal institutions on the business climate is not the same within each institution. A positive relationship was identified between business climate and business enabling policies, which goes in line with previous research [2], [33], [34]. However, business enabling policies do not seem to be an important factor in determining the business climate, which is similar to what Čadil et al. [43], Xheneti and Bartlett [20] and EBRD [70] concluded in their studies. The reason should be explored in the quality of the implemented business policies. An adoption of a similar framework for corporate / enterprise policy formulation, which Arshed et al. [71] suggested should lead to better results. Likewise, Xheneti [22] offers a conceptual framework for exploring policy formulation, linking policy formulation and the intended policy outcomes [14]. Business policies designed to improve the business environment should encourage or motivate business start-up and entrepreneurial activity. Policymakers should therefore insist on creating a friendly business environment and a well-functioning educational system [33] that would increase the supply of educated entrepreneurs [44].

Concerning tax treatment, a negative impact has been identified, which has supported the results of previous studies [2], [49], [50]. As stated in the literature review, the cumbersome regulatory framework and frequent changes in tax procedures may lead to the discouraging individuals from engaging in the business start-up process. As Jolley et al. [66] emphasized that, in order to improve the country's economy, entrepreneurs may prefer a policy that aims at reducing taxes rather than tax incentives or tax administrations that are procedure-based.

As mentioned in the official report of the European Commission [23], considerable efforts have been made in Albania to encourage individuals to engage in entrepreneurship and improve the business environment. This effort consists of establishing an action plan for cooperation between the government, industry and universities, and work on creating a friendly business environment for business start-ups. Nevertheless, further reforms encouraging entrepreneurial activity are needed to tackle deep-rooted obstacles, such as infrastructure (especially roads and electricity), property registration and contract enforcement [70].

Similar to formal institutions, even the informal ones do not have the same impact on the business climate. Our findings have shown the positive impact of corruption on the business climate supporting the "grease the wheels" theory of the business [57], [72]. This contradicts what was found in developed countries characterized by strong formal institutions, where corruption acts as an additional tax [47]. Corruption acts as the 'grease the wheels' for entrepreneurial activity in emerging and transition economies where there is an institutional weakness [17], [28], [73]. In addition, entrepreneurs cannot operate independently of corruption in these countries [74]. As Goel et al. [75] claims that entrepreneurs might also be 
involved in mutual corruption to counter law requirements. This could be seen as a result of operating in the environment consisting of both weak formal institutions and a weak entrepreneurial culture which lead to business owners being willing to avoid legal requirements or the attention of tax officials, and/or engage in bribery or corruption as a way of doing business.

Contrary to the main empirical literature, we have found that political connections have had a negative impact on business climate. This is in accordance with Jackowicz et al.'s [30] results. This should be related to the political instability characteristic for transition countries. Frequent changes of government officials may cause risky and unstable business connections with local or national politicians.

\section{Conclusion}

Scholars and policymakers consider entrepreneurship to be an important factor to stimulate the economic development, so many developed and developing countries have designed and implemented policies to support entrepreneurship [2], [32]. However, due to the differences in economic, institutional and political environments, the impact on business varies from country to country. This research focuses only on the influence of selected institutions on the business climate in the context of the transition economy.

The study based on institutional theory [9]-[11] seeks to examine and explore the relationship between selected institutions and business climate. This theory proves that the role of formal and informal institutions is very important for the business climate, especially for emerging and transition economies. Such institutions include business enabling policies, tax treatment, corruption and political connections. Compared to developed countries, improving the quality of institutions has a greater impact on the quality of business in developing countries [17]. We succeeded in answering the research question that appeared in the literature, regarding the institutional impact [2] on the business environment. Our study thus proves that neither formal institutions, nor informal ones act as a block concerning the effect on business climate.

Although our study has reached its aims, there are limitations in research. First, our findings are limited to one country, which might share the same conditions in terms of regional, economic, institutional and political environments with only limited number of countries. Therefore, our findings can be generalized only for developing and transition countries. Second, it is questionable to assume that the identified relationships could continue for infinite time and affect the business climate. Our results on tax treatment and political connections showed dubious effects that requires further investigation.

The study findings are beneficial for designing policies encouraging entrepreneurship and improving the business environment. That is why our results have been of a particular interest for policymakers, as the significant relationships 
between formal and informal institutions and the business climate have been identified. Consequently, this study contributes to a better understanding of the institutional theory.

\section{Acknowledgement}

The authors are thankful to the Internal Grant Agency project of Faculty of Management Economics, Tomas Bata University, "The role of institutional environment in fostering entrepreneurship", for financial support to carry out this research, and to IDRA Research and Consulting for giving us access to their data.

\section{References}

[1] R. Douhan and M. Henrekson, "Entrepreneurship and second-best institutions: going beyond Baumol's typology," J. Evol. Econ., Vol. 20, No. 4, pp. 629-643, Aug. 2010

[2] F. Chowdhury, D. B. Audretsch, and M. Belitski, "Institutions and Entrepreneurship Quality,” Entrep. Theory Pract., pp. 1-31, Sep. 2018

[3] T. S. Manolova, R. V. Eunni, and B. S. Gyoshev, "Institutional Environments for Entrepreneurship: Evidence from Emerging Economies in Eastern Europe," Entrep. Theory Pract., Vol. 32, No. 1, pp. 203-218, Dec. 2007

[4] P. Stenholm, Z. J. Acs, and R. Wuebker, "Exploring country-level institutional arrangements on the rate and type of entrepreneurial activity," J. Bus. Ventur., Vol. 28, No. 1, pp. 176-193, Jan. 2013

[5] J.-J. Dethier, M. Hirn, and S. Straub, "Explaining Enterprise Performance in Developing Countries with Business Climate Survey Data," World Bank Res. Obs., Vol. 26, No. 2, pp. 258-309, Aug. 2011

[6] H. Ghura, X. Li, and A. Harraf, "Moderating relationship of institutions for opportunity entrepreneurship and economic development," World J. Entrep. Manag. Sustain. Dev., Vol. 13, No. 4, pp. 350-374, Oct. 2017

[7] S. Dorado and M. J. Ventresca, "Crescive entrepreneurship in complex social problems: Institutional conditions for entrepreneurial engagement," J. Bus. Ventur., Vol. 28, No. 1, pp. 69-82, Jan. 2013

[8] R. S. Sobel, "Testing Baumol: Institutional quality and the productivity of entrepreneurship,” J. Bus. Ventur., Vol. 23, No. 6, pp. 641-655, Nov. 2008

[9] D. C. North, Institutions, institutional change, and economic performance. Cambridge University Press, 1990

[10] W. J. Baumol, "Entrepreneurship: Productive, Unproductive, and Destructive," J. Polit. Econ., Vol. 98, No. 5, Part 1, pp. 893-921, Oct. 1990

[11] O. E. Williamson, "The New Institutional Economics: Taking Stock, 
Looking Ahead," J. Econ. Lit., Vol. 38, No. 3, pp. 595-613, Sep. 2000

[12] F. Welter and D. Smallbone, "Institutional Perspectives on Entrepreneurial Behavior in Challenging Environments," J. Small Bus. Manag., Vol. 49, No. 1, pp. 107-125, Jan. 2011

[13] D. Smallbone and F. Welter, "Entrepreneurship and institutional change in transition economies: The Commonwealth of Independent States, Central and Eastern Europe and China compared," Entrep. Reg. Dev., Vol. 24, No. 3-4, pp. 215-233, Apr. 2012

[14] M. Xheneti and J. Kitching, "From Discourse to Implementation: Enterprise Policy Development in Postcommunist Albania," Environ. Plan. C Gov. Policy, Vol. 29, No. 6, pp. 1018-1036, Dec. 2011

[15] S. Estrin, J. Korosteleva, and T. Mickiewicz, "Which institutions encourage entrepreneurial growth aspirations?," J. Bus. Ventur., Vol. 28, No. 4, pp. 564-580, Jul. 2013

[16] S. Aparicio, D. Urbano, and D. Audretsch, "Institutional factors, opportunity entrepreneurship and economic growth: Panel data evidence," Technol. Forecast. Soc. Change, Vol. 102, pp. 45-61, Jan. 2016

[17] B. A. Krasniqi and S. Desai, "Institutional drivers of high-growth firms: country-level evidence from 26 transition economies," Small Bus. Econ., Vol. 47, No. 4, pp. 1075-1094, Dec. 2016

[18] T. Rajwani and T. A. Liedong, "Political activity and firm performance within nonmarket research: A review and international comparative assessment," J. World Bus., Vol. 50, No. 2, pp. 273-283, Apr. 2015

[19] EBRD (European Bank for Reconstruction and Development), "The business environment in the transition region," London, 2017

[20] M. Xheneti and W. Bartlett, "Institutional constraints and SME growth in post- communist Albania,” J. Small Bus. Enterp. Dev., Vol. 19, No. 4, pp. 607-626, Oct. 2012

[21] A. Bitzenis and E. Nito, "Obstacles to entrepreneurship in a transition business environment: the case of Albania," J. Small Bus. Enterp. Dev., Vol. 12, No. 4, pp. 564-578, Dec. 2005

[22] M. Xheneti, "Contexts of enterprise policy-making - an institutional perspective,” Entrep. Reg. Dev., Vol. 29, No. 3-4, pp. 317-339, Mar. 2017

[23] European Commission, "European Neighbourhood Policy and Enlargement Negotiations: 2017 SBA Fact Sheet Albania,” Brussel, 2017

[24] R. Osmani, "Improved Business Climate and FDI in the Western Balkans,” J. Econ. Soc. Stud., Vol. 6, No. 1, pp. 5-23, 2016

[25] Z. Kittova and D. Steinhauser, "The International Economic Position of Western Balkan Countries in Light of their European Integration 
Ambitions," J. Compet., Vol. 10, No. 3, pp. 51-68, 2018

[26] I. Verheul, S. Wennekers, D. Audretsch, and R. Thurik, "An Eclectic Theory of Entrepreneurship: Policies, Institutions and Culture," in Entrepreneurship: Determinants and Policy in a European-US Comparison, Boston: Kluwer Academic Publishers, 2002, pp. 11-81

[27] M. T. T. Thai and E. Turkina, "Macro-level determinants of formal entrepreneurship versus informal entrepreneurship," J. Bus. Ventur., Vol. 29, No. 4, pp. 490-510, Jul. 2014

[28] I. Hashi and B. A. Krasniqi, "Entrepreneurship and SME growth: evidence from advanced and laggard transition economies," Int. J. Entrep. Behav. Res., Vol. 17, No. 5, pp. 456-487, Aug. 2011

[29] M. Tomaszewski, "Corruption - A Dark Side of Entrepreneurship. Corruption and Innovations," Prague Econ. Pap., Vol. 27, No. 3, pp. 251269,2018

[30] K. Jackowicz, Ł. Kozłowski, and P. Mielcarz, "Political connections and operational performance of non-financial firms: New evidence from Poland," Emerg. Mark. Rev., Vol. 20, pp. 109-135, Sep. 2014

[31] H. G. Fereidouni and T. A. Masron, "Governance Matters and Entrepreneurial Activities," Thunderbird Int. Bus. Rev., Vol. 54, No. 5, pp. 701-712, Sep. 2012

[32] J. Belás, V. Demjan, J. Habánik, M. Hudáková, and J. Sipko, “The business environment of small and medium-sized enterprises in selected regions of the Czech Republic and Slovakia," E+M Ekon. a Manag., Vol. 18, No. 1, pp. 95-110, Mar. 2015

[33] Z. Brixiova and B. Égert, "Entrepreneurship, institutions and skills in lowincome countries," Econ. Model., Vol. 67, pp. 381-391, Dec. 2017

[34] Z. Brixiová and B. Égert, "Business environment, start-ups, and productivity during transition," Macroecon. Dyn., Vol. 16, No. S2, pp. 213-231, Sep. 2012

[35] C. Bjørnskov and N. Foss, "How Strategic Entrepreneurship and The Institutional Context Drive Economic Growth," Strateg. Entrep. J., Vol. 7, No. 1, pp. 50-69, Mar. 2013

[36] C. J. Surfield and C. S. Reddy, "Mass layoffs, manufacturing and state business climates: Does state policy matter?," Contemp. Econ. Policy, Vol. 34, No. 4, pp. 630-645, Oct. 2016

[37] L. Blume, "Local economic policies as determinants of the local business climate: Empirical results from a cross-section analysis among East German municipalities," Reg. Stud., Vol. 40, No. 4, pp. 321-333, Jun. 2006 
[38] J. Kolko, D. Neumark, and M. C. Mejia, "What do business climate indexes teach us about state policy and economic growth?," J. Reg. Sci., Vol. 53, No. 2, pp. 220-255, May 2013

[39] M. Xheneti and D. Smallbone, "The Role of Public Policy in Entrepreneurship Development in Post-Socialist Countries: A Comparison of Albania and Estonia,” EBS Rev., Vol. 24, pp. 23-36, 2008

[40] D. J. Cumming, L. Grilli, and S. Murtinu, "Governmental and independent venture capital investments in Europe: A firm-level performance analysis," J. Corp. Financ., Vol. 42, pp. 439-459, Feb. 2017

[41] M. Cepel, A. Stasiukynas, A. Kotaskova, and J. Dvorsky, "Business environment quality index in the SME segment," J. Compet., Vol. 10, No. 2, pp. 21-40, Jun. 2018

[42] A. Kljucnikov, J. Belas, L. Kozubikova, and P. Pasekova, "The Entreprenurial Perception of SME Business Environment Quality in the Czech Republic,” J. Compet., Vol. 8, No. 1, pp. 66-78, Mar. 2016

[43] J. Čadil, K. Mirošník, and J. Rehák, "The lack of short-term impact of cohesion policy on the competitiveness of SMEs," Int. Small Bus. J. Res. Entrep., Vol. 35, No. 8, pp. 991-1009, Dec. 2017

[44] R. La Porta and A. Shleifer, "Informality and Development," J. Econ. Perspect., Vol. 28, No. 3, pp. 109-126, Aug. 2014

[45] I. Hashi and J. Mladek, "Fiscal and Regulatory Impediments to the Entry of New Firms in Five Transition Economies," J. East-West Bus., Vol. 6, No. 2, pp. 59-94, Jan. 2001

[46] G. K. Batsakis, "Impediments on the way to entrepreneurship. Some new evidence from the EU's post-socialist world," J. Small Bus. Enterp. Dev., Vol. 21, No. 3, pp. 385-402, Aug. 2014

[47] M. Belitski, F. Chowdhury, and S. Desai, "Taxes, corruption, and entry," Small Bus. Econ., Vol. 47, No. 1, pp. 201-216, Jun. 2016

[48] J. I. Stallmann and S. Deller, "State Tax and Expenditure Limitations, Business Climate, and Economic Performance," Public Budg. Financ., Vol. 31, No. 4, pp. 109-135, Dec. 2011

[49] P. Braunerhjelm and J. E. Eklund, "Taxes, tax administrative burdens and new firm formation," Kyklos, Vol. 67, No. 1, pp. 1-11, Feb. 2014

[50] R. Aidis, S. Estrin, and T. M. Mickiewicz, "Size matters: entrepreneurial entry and government," Small Bus. Econ., Vol. 39, No. 1, pp. 119-139, Jul. 2012

[51] I. Verheul, A. Van Stel, and R. Thurik, "Explaining female and male entrepreneurship at the country level," Entrep. Reg. Dev., Vol. 18, No. 2, pp. 151-183, Mar. 2006 
[52] C. J. Boudreaux, B. N. Nikolaev, and R. G. Holcombe, "Corruption and destructive entrepreneurship," Small Bus. Econ., Vol. 51, No. 1, pp. 181202, Jun. 2018

[53] V. Tonoyan, R. Strohmeyer, M. Habib, and M. Perlitz, "Corruption and Entrepreneurship: How Formal and Informal Institutions Shape Small Firm Behavior in Transition and Mature Market Economies," Entrep. Theory Pract., Vol. 34, No. 5, pp. 803-831, Sep. 2010

[54] M. M. Khyareh, "Institutions and entrepreneurship: the mediating role of corruption," World J. Entrep. Manag. Sustain. Dev., Vol. 13, No. 3, pp. 262-282, Jul. 2017

[55] A. Grosanu and C. Bota-Avram, "The influence of country-level governance on business environment and entrepreneurship: A global perspective," Amfiteatru Econ., Vol. 17, No. 38, p. 60, 2015

[56] G. Dempster and J. Isaacs, "Entrepreneurship, corruption and economic freedom," J. Entrep. Public Policy, Vol. 6, No. 2, pp. 181-192, Aug. 2017

[57] A. Mohamadi, J. Peltonen, and J. Wincent, "Government efficiency and corruption: A country-level study with implications for entrepreneurship," J. Bus. Ventur. Insights, Vol. 8, pp. 50-55, Nov. 2017

[58] N. Dutta and R. Sobel, "Does corruption ever help entrepreneurship?," Small Bus. Econ., Vol. 47, No. 1, pp. 179-199, Jun. 2016

[59] D. Traikova, T. S. Manolova, J. Mollers, and G. Buchenrieder, "Corruption perception and entrepreneurial intention in a transitional context - the case of rural Bulgaria," J. Dev. Entrep., Vol. 22, No. 03, p. 1750018, Sep. 2017

[60] J. Budak and E. Rajh, "Corruption as an obstacle for doing business in the Western Balkans: A business sector perspective," Int. Small Bus. J., Vol. 32, No. 2, pp. 140-157, Mar. 2014

[61] H. Guo, E. Xu, and M. Jacobs, "Managerial political ties and firm performance during institutional transitions: An analysis of mediating mechanisms,” J. Bus. Res., Vol. 67, No. 2, pp. 116-127, Feb. 2014

[62] N. Boubakri, O. Guedhami, D. Mishra, and W. Saffar, "Political connections and the cost of equity capital," J. Corp. Financ., Vol. 18, No. 3, pp. 541-559, Jun. 2012

[63] S. Dicko, "Political connections, ownership structure and quality of governance," Int. J. Manag. Financ., Vol. 13, No. 4, pp. 358-377, Aug. 2017

[64] J. S. Ang, D. K. Ding, and T. Y. Thong, "Political Connection and Firm Value," Asian Dev. Rev., Vol. 30, No. 2, pp. 131-166, Sep. 2013

[65] M. D. Amore and M. Bennedsen, "The value of local political connections 
in a low-corruption environment," J. financ. econ., Vol. 110, No. 2, pp. 387-402, Nov. 2013

[66] G. J. Jolley, M. F. Lancaster, and J. Gao, "Tax Incentives and Business Climate: Executive Perceptions From Incented and Nonincented Firms," Econ. Dev. Q., Vol. 29, No. 2, pp. 180-186, May 2015

[67] R. F. DeVellis, Scale development: theory and applications, $4^{\text {th }}$ ed. SAGE Publications, 2017

[68] F. E. Harrell, Regression Modeling Strategies: With Applications to Linear Models, Logistic and Ordinal Regression, and Survival Analysis, $2^{\text {nd }}$ ed. Springer, 2015

[69] M. J. Norušis, IBM SPSS statistics 19 advanced statistical procedures companion. Prentice Hall, 2012

[70] EBRD (European Bank for Reconstruction and Development), "Country assessments: Albania," 2018

[71] N. Arshed, S. Carter, and C. Mason, "The ineffectiveness of entrepreneurship policy: is policy formulation to blame?," Small Bus. Econ., Vol. 43, No. 3, pp. 639-659, Oct. 2014

[72] P.-G. Méon and L. Weill, "Is Corruption an Efficient Grease?," World Dev., Vol. 38, No. 3, pp. 244-259, Mar. 2010

[73] A. Dreher and M. Gassebner, "Greasing the wheels? The impact of regulations and corruption on firm entry," Public Choice, Vol. 155, No. 34, pp. 413-432, Jun. 2013

[74] N. Williams and T. Vorley, "Fostering productive entrepreneurship in post-conflict economies: the importance of institutional alignment," Entrep. Reg. Dev., Vol. 29, No. 5-6, pp. 444-466, May 2017

[75] R. K. Goel, J. Budak, and E. Rajh, "Private sector bribery and effectiveness of anti-corruption policies," Appl. Econ. Lett., Vol. 22, No. 10, pp. 759-766, Jul. 2015 